\title{
Evaluation of the ecoefficiency of greenhouse gases generation in the provision of complementary meals in a public hospital
}

\author{
Avaliação da ecoeficiência de geração de gases de efeito estufa na oferta de alimentação \\ complementar em hospital público \\ Evaluación de la Ecoeficiencia de la generación de gases de efecto invernadero en la provisión de \\ comidas complementarias en un hospital público
}

Received: 03/17/2021 | Reviewed: 03/23/2021 |Accept: 03/24/2021 | Published: 04/01/2021

Karla Renata Romagna Ribeiro

ORCID: https://orcid.org/0000-0002-8898-0474

Universidade Federal do Rio Grande do Sul, Brazil

E-mail: karlarenatarr@gmail.com

Priscilla Moura Rolim

ORCID: https://orcid.org/0000-0002-3847-5744 Universidade Federal do Rio Grande do Norte, Brazil E-mail: priscillanutri@hotmail.com

Larissa Mont'Alverne Jucá Seabra

ORCID: https://orcid.org /0000-0002-1878-4283 Universidade Federal do Rio Grande do Norte, Brazil E-mail: larissaseabra@yahoo.com.br

Virgílio José Strasburg

ORCID: https://orcid.org/0000-0001-8536-6092 Universidade Federal do Rio Grande do Sul, Brazil E-mail:virgilio_nut@ufrgs.br

\begin{abstract}
The present study aimed to assess Ecoefficiency (EE) related to the emission of Greenhouse Gases (GHG) from the transport of the inputs used to provide complementary meals at a large university hospital in Brazil. For EE calculations, the annual energy supply in kilocalories of the inputs used and the estimated GHG emissions were considered, considering the distance in kilometers between the place of origin of each product and the destination city in southern Brazil. 31 products were used and selected for complementary meals distributed in the groups of: dairy products, cookies, drinks, supplements, and enteral diets for adults and pediatrics. The results showed that EE was directly related to the origin of the products, especially in enteral diets. The application of the Spearman correlation coefficient showed a strong negative correlation of -0.8119 [CI (95\%) - $0.9023 ;-0.6531]$ between the variables distance in kilometers and eco-efficiency and also when comparing GHG emissions with kilocalories. The health sector must play its role in relation to environmental impacts also in the assessment of GHG emissions in the context of nutritional therapy.
\end{abstract}

Keywords: Dietotherapy; Environmental impacts; Food services; Transportation.

\section{Resumo}

O presente estudo teve como objetivo avaliar a Ecoeficiência (EE) relacionada com a emissão de Gases de Efeito estufa (GEE) do transporte dos insumos utilizados para o fornecimento de refeições complementares de um hospital universitário de grande porte no Brasil. Para os cálculos da EE foram considerados o suprimento anual de energia em quilocalorias dos insumos utilizados e as emissões estimadas de GEE, considerando a distância em quilômetros entre o local de origem de cada produto e a cidade de destino no sul do Brasil. Foram selecionados e avaliados 31 produtos utilizados para as refeições complementares distribuídos nos grupos de: laticínios, biscoitos, bebidas, suplementos, e dietas enterais para adultos e pediatria. Os resultados mostraram que a EE esteve diretamente relacionada ao local de origem dos produtos, especialmente nas dietas enterais. A aplicação do coeficiente de correlação de Spearman mostrou forte correlação negativa de $-0,8119$ [IC (95\%) -0,9023; -0,6531] entre as variáveis distância em quilômetros e ecoeficiência e também na comparação entre emissão de GEE com quilocalorias. O setor da saúde deve desempenhar seu papel com relação aos impactos ambientais também na avaliação da emissão de GEE no contexto da terapia nutricional.

Palavras-chave: Dietoterapia; Impactos ambientais; Serviços de alimentação, Transporte.

\section{Resumen}

El presente estudio tuvo como objetivo evaluar la Ecoeficiencia (EE) relacionada con la emisión de gases de efecto invernadero (GEI) del transporte de insumos utilizados para proporcionar comidas complementarias en un gran hospital 
universitario de Brasil. Para los cálculos de EE se consideró el suministro anual de energía en kilocalorías de los insumos utilizados y las emisiones de GEI estimadas, considerando la distancia en kilómetros entre el lugar de origen de cada producto y la ciudad de destino en el sur de Brasil. Se utilizaron y seleccionaron 31 productos para las comidas complementarias distribuidos en los siguientes grupos: lácteos, galletas, bebidas, suplementos y dietas enterales para adultos y pediatría. Los resultados mostraron que la EE estaba directamente relacionada con el lugar de origen de los productos, especialmente en las dietas enterales. La aplicación del coeficiente de correlación de Spearman mostró una fuerte correlación negativa de -0,8119 [IC (95\%) -0,9023; -0,6531] entre las variables distancia en kilómetros y ecoeficiencia y también al comparar emisiones de GEI con kilocalorías. El sector de la salud debe desempeñar su papel en relación con los impactos ambientales también en la evaluación de las emisiones de GEI en el contexto de la terapia nutricional.

Palabras clave: Dietoterapia; Impactos ambientales; Alimentos; Servicios de transporte.

\section{Introduction}

Environmental Management comprises a set of administrative and operational techniques, policies and strategies used by a company or institution to monitor and control the impact of its actions on the environment (Yu \& Ramanathan, 2016). There are several environmental impact indicators available, whose assessment methods are generally based on the quantification of substances harmful to the environment (Cerutti, et al., 2016).

The Eco-efficiency (EE) is used to assess a company's economic and environmental impacts (Carvalho, et al., 2017). EE's objective is to create more with less impacts, generating quality of life and prices that meet human needs, reducing the quantity and intensity of environmental impacts throughout the product's life cycle (WBCSD, 2000). They are used as the most frequent indicators in EE calculations: material consumption, energy and water consumption, greenhouse gas emissions, toxicity potential and risk potential (Caiado, et al., 2017).

According to the Kyoto Protocol, the six greenhouse gases (GHG) are carbon dioxide $\left(\mathrm{CO}_{2}\right)$, methane $\left(\mathrm{CH}_{4}\right)$, nitrous oxide $\left(\mathrm{N}_{2} \mathrm{O}\right)$, hydrofluorocarbons (HFCs), perfluorocarbons (PFCs) and sulfur hexafluoride ( $\mathrm{SF}_{6}$ ) (Carbon Trust, 2020). Emissions of these six gases are taken into account for the calculation of the carbon footprint indicator of products, which counts the total emission of GHG in $\mathrm{CO}_{2}$ equivalents $\left(\mathrm{CO}_{2} \mathrm{e}\right)$ (Caiado, et al., 2017). Such emissions may be caused directly or indirectly by persons, organizations, events or products (Carbon Trust, 2020).

According to data from the United States Environmental Protection Agency, the main sources of greenhouse gas emissions in the United States are: transport, electricity production, industry, commercial and residential, agriculture, land use and forestry (EPA, 2020). The GHG most produced by human activities is $\mathrm{CO}_{2}$, which has direct sources of emission such as the burning of fossil fuels for the generation of electricity, heating and transportation (ECCM, 2008).

Food production systems are responsible worldwide for a significant share of total greenhouse gases (GHG) emissions, from the emissions generated in the production and transportation of raw material to the procedures used during their transformation into the final product (Carbon Trust, 2020). Food production is estimated to account for $26 \%$ of global GHG emissions (Ritchie \& Roser, 2020).

In the hospital context, the provision of meals by the Nutrition Service plays a fundamental role in the recovery and conservation of health, with a view to meeting the nutritional needs of patients and contributing to their clinical improvement (Simzari, et al., 2017). It is important to standardize the types of diets offered to ensure greater efficiency in care. Hospital diets are generally subdivided into: routine diets, diets modified in terms of composition, special diets and diets for exam preparation (Abreu, et al., 2016). The prescription of the diet and the number of meals a patient can receive will be related to his health and nutritional status.

Therefore, this study aims to evaluate the Eco-efficiency related to the emission of greenhouse gases from transport in the supply of complementary meals offered to patients at a large university hospital in Brazil. 


\section{Methodology}

\section{General characterization}

This research is characterized as a cross-sectional, retrospective study, using quantitative document analysis, using secondary data (Prodanov \& Freitas, 2013). This database was collected at a university hospital in the city of Porto Alegre, in the state of Rio Grande do Sul, Brazil. When this study was conducted, the hospital had 842 hospitalization beds. Patients received up to seven meals per day distributed in two modalities: 1) main meals (breakfast, lunch, afternoon snack and dinner); and 2) Complementary (collation, late night snack between $8 \mathrm{pm}$ and $10 \mathrm{pm}$ ).

This study's data refer to the consumption of complementary meals. The choice for this type of meals is justified by the fact that they are considered 'nutritional therapy' and are used, especially, to prevent and treat cases of malnutrition, and also to improve the immune and healing response of patients.

\section{Inclusion criteria}

For each food item that composed the database, the following information was collected: product description; manufacturer; city and country of origin; the total weight of the package and total kilocalories (kcal). All the chosen products had packaging containing the nutritional information and production data, thus presenting greater accuracy in the identification of manufacturers and distributors. Data collection took place during January 2018, on the premises of the study site. A Microsoft Excel@ spreadsheet was created for data consolidation. The study was approved by the Research Ethics Committee of the Federal University of Rio Grande do Sul School of Medicine, under process number 34786/2018.

The acquired food products were grouped, for convenience, into six groups according to its characteristics: 1) industrialized enteral formulas (IEF) for adults; 2) IEF for pediatrics; 3) dairy products; 4) supplements; 5) cookies; 6) beverages. Each group's food products were selected based on a minimum of $85 \%$ of the total consumption in kilograms of the items (ABC analysis) as proposed in the study by Strasburg and Jahno (2017).

\section{Data collect}

In order to calculate the environmental influence, the following items were selected:

1 - Distance from the origin of the acquired food product. It considered the distance from the place of industrial production of the food to the city of Porto Alegre. Mileage values $(\mathrm{km})$ between Porto Alegre and the cities of origin of the products were calculated through the website "Distância entre cidades" (in English, "Distance between cities") taking into account the shortest distance between two points (Wepoke, 2018). This tool uses as database the report of the National Department of Transport Infrastructure (DNIT) of Brazil. The study followed a protocol similar to the one used by De Laurentiis et al. (2018).

2 - Greenhouse Gases (GHG). Calculated for the transport distance (in kilometers) of the food products purchased from the six groups informed in the item describing the population. For determining the emissions GHG were considered the data presented in the table Greenhouse gas reporting: conversion factors (DECC, 2017).

Regarding the type of vehicle used, the researchers chose, for convenience, the model of medium vans with diesel engine, which emit $0.25749 \mathrm{kgCO}_{2} \mathrm{e}$ per kilometer traveled in the atmosphere. This factor is considered to be a limitation of this study. However, this choosing is justified by the fact it is not possible to track all logistical operations of each manufacturer, which may use different types of vehicles and transport steps for delivering to the final destination.

In the context of eco-efficiency, the following equation is used as the parameter (WBCSD, 2000):

Eco-efficiency $=$ product or service value

environmental influence 
The financial value of the inputs evaluated in this study was not considered for EE calculations. Since the institution acquires its inputs through subsidized prices for being a public agency, it does not represent the real market value of the items studied. In place of the financial value in the EE assessment, the energy value ( $\mathrm{kcal}$ ) of the food item was used in relation to the amount used.

To obtain the product value information, the following steps were taken:

1 - Total consumption quantification of the inputs used in the supply of industrialized enteral formulas, supplements, and food products for complementary meals in absolute values (kilograms) acquired in the year 2017.

2 - Verification of the caloric value (kcal) of each input used. As all the inputs used were industrialized, the information on the packaging regarding the energy value was considered. For the calculation of the total energy value, a standardization was performed considering the energy adjustment per kilogram or liter of net weight input in relation to the total amount acquired.

For the EE calculation, it was evaluated the relation between the total kilocalories for a kilogram of each product and the distance traveled in the transport between its manufacturing site and the city of Porto Alegre. The results were compared to relate the energy value of the inputs in relation to the distance from the source and, subsequently, to quantify the GHG emission from transport.

\section{Data analysis}

The quantitative variables of the study such as total, average frequency and coefficients of variation were calculated using Microsoft ${ }^{\circledR}$ Excel 2010 software and presented in tables and figure.

Statistical analysis was performed using the R Project 3.5.3® software. Spearman correlation was calculated due to the asymmetric nature of the variables involved (type of products, origin and distance) (Gibbons \& Chakraborti, 2003). This test is recommended when the sample size does not present a large amount of data.

\section{Results and Discussion}

Chart 1 describes the products of each food group.

Chart 1. Description of the groups

\begin{tabular}{|l|l|l|}
\hline \multicolumn{1}{|c|}{ Group } & $\mathbf{N}^{\circ}$ & \multicolumn{1}{|c|}{ Products } \\
\hline IEF* for adults & 14 & Liquid polymeric diets with variations from 1 to 2 kcal/ml. \\
\hline IEF for pediatrics & 4 & Nutritionally complete and enriched formulas. \\
\hline Supplements & 4 & $\begin{array}{l}\text { Products such as maltodextrin and hydrolyzed whey protein, thickener } \\
\text { and gelling agent. }\end{array}$ \\
\hline Dairy products & 3 & Various yogurts (fruit pulp, natural skim and diet). \\
\hline Cookies & 3 & $\begin{array}{l}\text { Various cookies such as 'water and salt', Maria (Marie biscuit) and light } \\
\text { salt. }\end{array}$ \\
\hline Beverages & 3 & Varies juices (with sugar, without sugar, and soy-based drinks). \\
\hline
\end{tabular}

Source: authors. *IEF - industrialized enteral formulas

The six groups of items evaluated are used according to the specific dietary needs of the patients, which influences in the acquisition amount and origin of the inputs. 
The liquid IEF for adults may be used in enteral nutritional therapy for patients using nasoenteric catheter, gastrostomy, and jejunostomy, or to complement the oral feeding of patients (Mahan, et al., 2012; Brasil, 2000). Tosatti et al. (2019) identified the importance of using adult enteral formulas in the nutritional support of patients.

The IEF group for pediatrics encompassed nutritionally complete powder diets specifically designed to meet the needs of children at different stages of life. According to Krom et al. (2019) the main pathologies requiring enteral feeding for children are congenital anomalies, perinatal complications, and neurological diseases. For IEF for pediatrics, the proportion between domestic and imported products had the same percentage (50\%).

The supplements products are essential to patients who require greater daily caloric intake. Nutrient-concentrated and isolated products for modifying consistency through their functional properties are also important. Food thickeners, for instance, are essential in the management of dysphagia, since it improves swallowing control and helps prevent aspiration (Cichero, 2013). In this study, $66.6 \%$ of the total of this type of products were supplied by Brazilian companies.

Dairy products, cookies, and beverages are groups present only in the complementation of the menu of patients who are able to receive oral feeding, varying according to individual pathologies and limitations.

Table 1 shows the energy distribution of the inputs used.

Table 1. Food groups and the relationship between the amount of energy supply and the annual consumption of inputs used in a hospital in Porto Alegre, Brazil.

\begin{tabular}{ccccc}
\hline Group & $\mathbf{n}$ & $\begin{array}{c}\text { Total energy } \\
\text { supply } \\
(\mathbf{k c a l})\end{array}$ & $\begin{array}{c}\text { Annual } \\
\text { consumption }\end{array}$ & $\begin{array}{c}\text { Relation Energy / } \\
\text { Annual } \\
\text { consumption }\end{array}$ \\
\hline IEF adults & 14 & 36348104 & $34123.8 \mathrm{~L}$ & 1065.2 \\
IEF pediatrics & 4 & 3015051.8 & $1643.7 \mathrm{~kg}$ & 1834.3 \\
Supplements & 4 & 2124468.5 & $1084.9 \mathrm{~kg}$ & 1958.2 \\
Cookies & 3 & 4830592 & $5201 \mathrm{~kg}$ & 928.8 \\
Dairy & 3 & 372377267.6 & $301163 \mathrm{~kg}$ & 1236.5 \\
Beverages & 3 & 136429405 & $482081 \mathrm{~L}$ & 283.0 \\
\hline \multicolumn{5}{c}{} \\
\hline
\end{tabular}

Table 1 shows the six input food groups. Of these, the 31 food items were purchased from 20 different suppliers from different countries: Brazil (13), Germany (3), Netherlands (1), United States of America (USA) (1), China (1), and England (1). It was observed that although the institution bought most products from countries like Brazil and Germany, the suppliers of the same ones were repeated. More than half (64.3\%) of the total products in the group IEF for adults were purchased from countries other than Brazil.

IEF for adults, cookies, dairy products and, beverages presented higher annual consumption, as well as higher energy supply. In the dairy, cookies and beverage groups, all acquired products came from Brazil. Rio Grande do Sul and Paraná were the two states that supplied the most to the institution, being responsible for supplying $63.2 \%$ of the food needed.

In general scope, the leading country in imports was Germany, supplying $22.5 \%$ of the food products purchased by the university hospital focus of this study, followed by the Netherlands, the USA, China, and England, respectively. It is identified 
that the largest share of acquired food products is originally produced in Brazil, representing $61.2 \%$ of the total purchased and $96.7 \%$ of the energy value.

Table 2 highlights that in the comparative evaluation between the total energetic value provided and the distance traveled in the transport, the ratio was always higher for products from Brazil. Imported products from the USA presented the secondbest EE relation followed by England, Germany, China, and Holland. Although, in this study, the Netherlands is closer to China in terms of distance $(\mathrm{km})$, a lower ratio was shown because it provided much lower energy values.

The IEF for adults and pediatrics, as well as the supplements, were those that presented higher energy supply per kilogram or liter of a product. Tosatti et al. (2019) evaluated the use of nine adult enteral formulas (from five different countries) to verify the glycemic index they provided to patients. Differences in density and total energy were found between the enteral diets used in the study. In this context, the importance of homemade or made from scratch diets is highlighted as an alternative to the consumption of industrialized diets in hospitals (Kutz, et al., 2018).

Table 2. Eco-efficiency: Evaluation of total annual energy supply of the inputs in relation to the distance of origin.

\begin{tabular}{|c|c|c|c|}
\hline IEF & & & \\
\hline adults & kcal/package * & Distance (km) & $\mathbf{E E}$ \\
\hline Brazil & 1434 & 832.07 & 1.723 \\
\hline Germany & 887.5 & 10689.61 & 0.083 \\
\hline Netherlands & 474.3 & 10624.86 & 0.045 \\
\hline China & 1000 & 19117.72 & 0.052 \\
\hline \multicolumn{4}{|l|}{ IEF } \\
\hline pediatrics & kcal/package & Distance(km) & $\mathbf{E E}$ \\
\hline Brazil & 1828.6 & 788.79 & 2.318 \\
\hline England & 1932 & 10389.37 & 0.186 \\
\hline USA & 2000 & 8855.77 & 0.226 \\
\hline Supplements & kcal/package & Distance(km) & $\mathbf{E E}$ \\
\hline Brazil & 2257.5 & 1616.64 & 1.396 \\
\hline Germany & 1050 & 10779.69 & 0.097 \\
\hline Cookies & kcal/package & Distance(km) & $\mathbf{E E}$ \\
\hline Brazil & 1392 & 357.82 & 3.890 \\
\hline Dairy & kcal/package & Distance(km) & $\mathbf{E E}$ \\
\hline Brazil & 791.05 & 469.82 & 1.684 \\
\hline Beverages & kcal/package & Distance(km) & $\mathbf{E E}$ \\
\hline Brazil & 456.67 & 469.9 & 0.972 \\
\hline
\end{tabular}

Source: authors. ${ }^{*} \mathrm{kcal} /$ package= adjusted for kilogram or liter of net weight 
By applying the Spearman correlation coefficient between the distance and kilometers variables and EE between all product groups, a strong negative correlation of -0.8119 was found [CI $(95 \%)-0.9023 ;-0.6531$ ]. Thus, the lowest EE values were related to the distance to countries from where purchased products were sent.

Table 3 shows that the calorie CO2e ratio is higher the greater the distance from the acquired food item country of production. The Brazilian products were those with the lowest $\mathrm{CO} 2$ emission, with an average of $0.25 \mathrm{~kg}$ of $\mathrm{CO} 2 \mathrm{per} \mathrm{kcal}$ of the transported product.

However, it should be noted that, especially in relation to IEF (adult and pediatric), the products' greatest component is water, makes such finding even more relevant. In a study that evaluated enteral diets in Brazil, Castro e Cardoso et al. (2018) identified that out of the 74 formulations analyzed, $87.8 \%$ were sold in liquid form.

In applying Spearman's correlation coefficient to evaluate the CO2e/kcal variables with the products' EE of all six groups, a strong negative correlation was found: -0.8904548 [CI (95\%) -0.9442782; -0.7902502]. Thus, it can be characterized that the greater the distance of the product's production location, the lower the energy efficiency of the same.

Table 3. Evaluation of eco-efficiency in the emission of GHG of inputs in relation to their total annual energy supply acquired at a university hospital. Porto Alegre, Brazil.

\begin{tabular}{|c|c|c|c|}
\hline $\begin{array}{c}\text { IEF } \\
\text { adults }\end{array}$ & kcal/package* & Emission $\mathrm{kgCO}_{2} \mathrm{e}$ & $\mathrm{CO}_{2} \mathrm{e} / \mathrm{kcal}$ \\
\hline Brazil & 1434 & 214.25 & 0.15 \\
\hline Germany & 887.5 & 2752.47 & 3.10 \\
\hline Netherlands & 474.3 & 2735.80 & 5.77 \\
\hline China & 1000 & 4922.62 & 4.92 \\
\hline \multicolumn{4}{|l|}{ IEF } \\
\hline pediatrics & kcal/package * & Emission $\mathrm{kgCO}_{2} \mathrm{e}$ & $\mathrm{CO}_{2} \mathrm{e} / \mathrm{kcal}$ \\
\hline Brazil & 1828.60 & 203.11 & 0.11 \\
\hline England & 1932 & 2675.16 & 1.38 \\
\hline USA & 2000 & 2280.27 & 1.14 \\
\hline Supplements & kcal/package $^{*}$ & Emission $\mathrm{kgCO}_{2} \mathrm{e}$ & $\mathrm{CO}_{2} \mathrm{e} / \mathrm{kcal}$ \\
\hline Brazil & 2257.50 & 416.27 & 0.18 \\
\hline Germany & 1050 & 2775.66 & 2.64 \\
\hline Cookies & kcal/package ${ }^{*}$ & Emission $\mathrm{kgCO}_{2} \mathrm{e}$ & $\mathrm{CO}_{2} \mathrm{e} / \mathrm{kcal}$ \\
\hline Brazil & 1392 & 92.14 & 0.07 \\
\hline Dairy & kcal/package $^{*}$ & Emission $\mathrm{kgCO}_{2} \mathrm{e}$ & $\mathrm{CO}_{2} \mathrm{e} / \mathrm{kcal}$ \\
\hline Brazil & 791.05 & 120.97 & 0.59 \\
\hline Beverages & kcal/package* $^{*}$ & Emission $\mathrm{kgCO}_{2} \mathrm{e}$ & $\mathrm{CO}_{2} \mathrm{e} / \mathrm{kcal}$ \\
\hline Brazil & 456.67 & 120.99 & 0.26 \\
\hline
\end{tabular}


The results of Figure 1 show that products from Brazil have the lowest amounts of GHG since the distance traveled between states is much shorter than the distance covered by imported products to the site here in study. This result corroborates with the study by De Laurentiis et al. (2018) that found that food products purchased within the United Kingdom itself had reduced GHG emissions compared to those originating outside the country when purchased during the harvest period and without the need for greenhouse cultivation.

Figure 1. Emissions of GHG $(\mathrm{kgCO} 2 \mathrm{e})$ in the transportation of foodstuffs groups by each country used in a Brazilian public hospital.

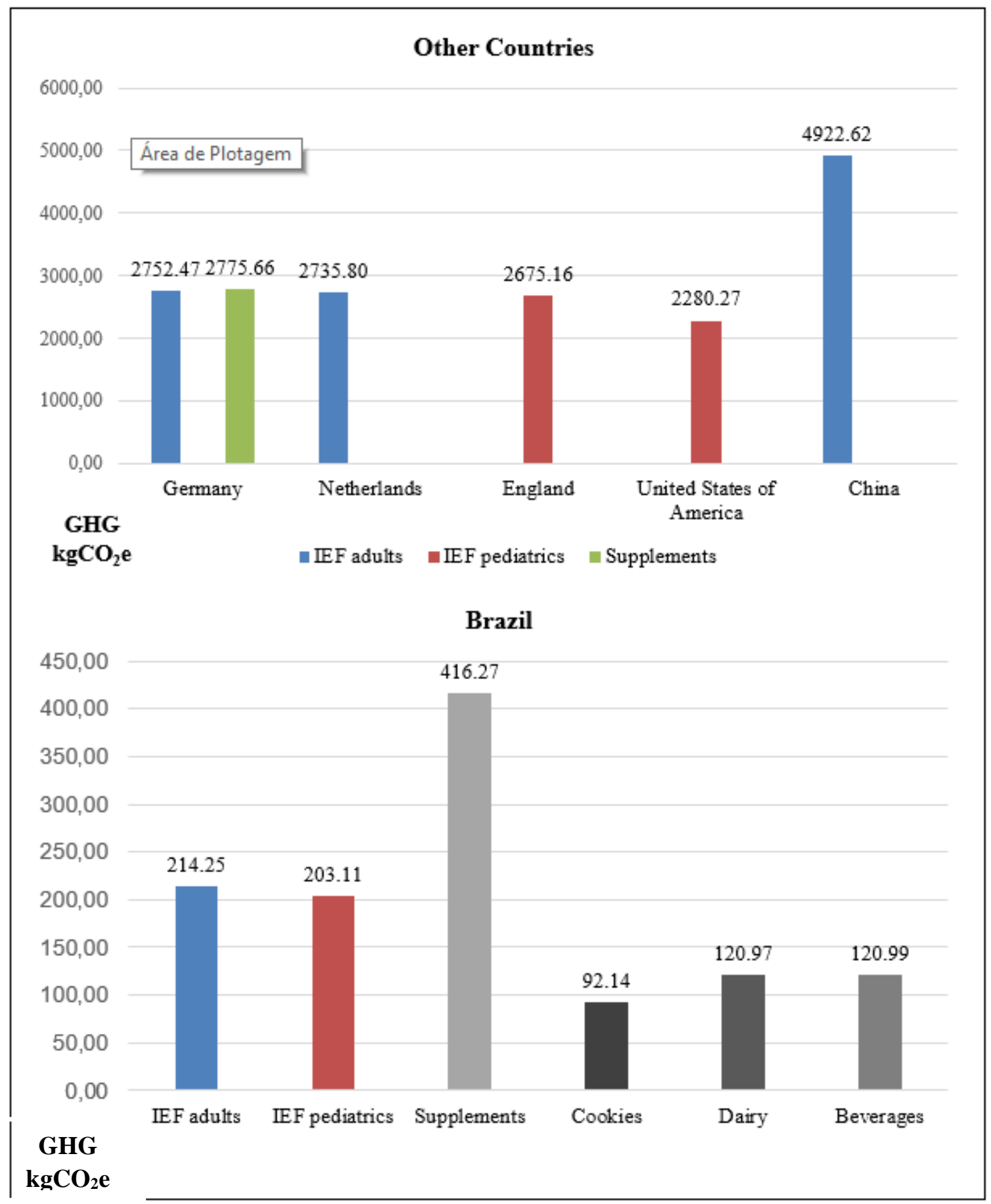

Source: authors. 
Hallström et al. (2018) highlighted in their systematic review study that there are currently several diet quality indices being used in studies to assess environmental and nutritional issues. The use of EE was also applied by Strasburg and Jahno (2017) to assess the different types of inputs used in university restaurant foodservices.

It is important to highlight that imported products could present $\mathrm{CO} 2$ emissions even higher than those found in this study when transported by sea or air (De Laurentiis, et al., 2017). We emphasize that the transportation calculation only considered the distance of the manufactured product without considering the origin of the raw materials purchased by the manufacturers.

In general, in the last decades, food production has been evaluated in relation to the standardization of consumption habits and also in terms of environmental impacts, which will lead to a series of problems for the planet related to the increased GHG emissions, the use of agricultural land and the consumption of fresh water, if no changes take place by the year 2050 (Willett, et al., 2019). Thus, this concern and care also apply to the hospital sector.

\section{Final Considerations}

Being a field with several particularities and favorable to causing environmental impacts, this study sought new alternatives to evaluate environmental performance in the context of hospital diets.

This study sought to explore new possibilities for the calculation of EE concerning the supply of meals to specific populations. The results of the study describe that Brazilian products were more eco-efficient than imported products in the comparative assessment of the total energy supplied in relation to the transport distance.

Regarding the calculation of the GHG, the products from Brazil were again those that showed less environmental impact. These products presented the lowest amount of emission of $\mathrm{kgCO} 2 \mathrm{e}$ since the distance for transportation between states is much smaller than that traveled by imported products on the way to their destination sites.

Thus, this study highlights the importance of encouraging not only the stimulation of greater national trade, but also its development and improvement, since, in many cases, it is necessary to search for specific formulas from other countries due to the different processes that are used during their manufacturing.

Faced with the negative consequences of climate change and unsustainable use of resources on health systems, further research should be conducted to quantify environmental impacts and seek solutions to the crisis affecting the environment and public health. The use of environmental indicators is a resource to carry out analyzes of the evolution of environmental impacts over time, and not only in specific assessments.

Studies on the theme presented in this article are being developed in order to more accurately identify the impacts of the generation of greenhouse gases according to the types of transport used, including land and sea for long distances. In addition, calculations for the carbon footprint for foods used in the provision of hospital meals will also be considered.

\section{Acknowledgements}

To the Nutritionists Lúcia Pereira de Souza and Denise Eberhardt of the Hospital de Clinicas de Porto Alegre (HCPA) for the support in data collection.

\section{Disclosure Statement}

This research did not receive any specific grant from funding agencies in the public or private sectors. 


\section{References}

Abreu, E. S., Spinelli, M. G. N., \& Zanardi, A. M. P. (2016). Gestão de Unidades de Alimentação e Nutrição: um modo de fazer, (3rd ed.), Metha.

Brasil. (2000). $R D C N^{\circ}$ 63, de 6 de julho de 2000. Dispõe sobre o regulamento Técnico para fixar os requisitos mínimos exigidos para a Terapia de Nutrição Enteral. Ministério da Saúde. Agência Nacional de Vigilância Sanitária. Resolução da Diretoria Colegiada. http://bvsms.saude.gov.br/bvs/saudelegis/anvisa/2000/rdc0063_06_07_2000.html

Caiado, R. G. G., Dias, R. F., Mattos, L. V., et al. (2017). Towards sustainable development through the perspective of eco-efficiency - A systematic literature review. J Clean Prod. 165, 890-904. https://doi.org/10.1016/j.jclepro.2017.07.166

Carbon trust. (2020). Carbon footprinting guide. https://www.carbontrust.com/resources/guides/carbon-footprinting-and-reporting/carbon-footprinting/

Carvalho, H., Cruz-Machado, V., Govindan, K., et al. (2017). Modelling green and lean supply chains: An eco-efficiency perspective. Resour Conserv Recycling, 120, 75-87. https://doi.org/10.1016/j.resconrec.2016.09.025

Castro e Cardoso, M. G., Prates, S. M. S., \& Anastácio, L. R. (2018). Fórmulas para nutrição enteral padrão e modificada disponíveis no Brasil: Levantamento e classificação. BRASPEN J. 33 (4), 402-17. http://arquivos.braspen.org/journal/out-dez-2018/08formulas.pdf

Cerutti, A. K., Contu, S., Ardente, F., et al. (2016). Carbon footprint in green public procurement: Policy evaluation from a case study in the food sector. Food Policy, 58, 82-93. https://doi.org/10.1016/j.foodpol.2015.12.001

Cichero, J. A. Y. (2013). Thickening agents used for dysphagia management: effect on bioavailability of water, medication and feelings of satiety. Nutr J., 12 (54), 1-8. https://doi.org/10.1186/1475-2891-12-54

DECC (Department of Energy \& Climate Change). (2017). Greenhouse gas reporting - Conversion factors. https://www.gov.uk/government/publications/greenhouse-gas-reporting-conversion-factors-2017

De Laurentiis V., Hunt, D. V. L., \& Rogers, C. D. F. (2017). The Little Book of LOW CARBON EATING in the city. Lancaster University, Lancaster. file://C:/Users/123/Downloads/LittleBookofLowCarbonEatinginthecity.pdf

De Laurentiis, V., Hunt, D. V. L., Lee, S. E., et al. (2018). EATS: a life cycle-based decision support tool for local authorities and school caterers. Int J Life Cycle Assess. 24 (7), 1222-1238. https://doi.org/10.1007/s11367-018-1460-x.

ECCM (Edinburg Centre of Carbon Management). (2008). What is a carbon footprint? http://www.timcon.org/CarbonCalculator/Carbon\%20Footprint.pdf

EPA (United States Environmental Protection Agency). (2020). Sources of Greenhouse Gas Emissions. https://www.epa.gov/ghgemissions/sources-greenhousegas-emissions

Gibbons, J. D., \& Chakraborti, S. (2003). Nonparametric Statistical Inference, fourth ed.: Marcel Dekker Inc.

Krom, H., Van Zundert, S. M. C., Otten, M. A. G. M., et al. (2019). Prevalence and side effects of pediatric home tube feeding. Clin Nutr., 38 (1), 234-239. https://doi.org/10.1016/j.clnu.2018.01.027

Kutz, N. A., Bonfim, V. A. S., Assis, A. L., et al. (2018). Padronização de dietas enterais artesanais para uso domiciliar na Atenção Primária. Revista Família, Ciclos de Vida e Saúde no Contexto Social, 6 (1), 298-305. https://doi.org/10.18554/refacs.v6i0.2900

Mahan, L. K., Escott-Stump, S., \& Raymond, J. L. (2012). Krause-Alimentos, Nutrição e Dietoterapia, thirteenth ed: Elsevier.

Prodanov, C. C., \& Freitas, E. C. (2013). Metodologia do trabalho científico: métodos e técnicas da pesquisa e do trabalho acadêmico. Novo Hamburgo: Feevale. http://www.feevale.br/Comum/midias/8807f05a-14d0-4d5b-b1ad-1538f3aef538/E-book\%20Metodologia\%20do\%20Trabalho\%20Cientifico.pdf.

Ritchie, H., \& Roser, M. (2020). Environmental impacts of food production. Published online at OurWorldInData.org. https://ourworldindata.org/environmentalimpacts-of-food

Simzari, K., Vahabzadeh, D., Saeidlou, S. N., et al. (2017). Food intake, plate waste and its association with malnutrition in hospitalized patients. Nutr Hosp., 34 (5), 1376-1381. http://dx.doi.org/10.20960/nh.1102

Strasburg, V. J., \& Jahno, V. D. (2017). Application of eco-efficiency in the assessment of raw materials consumed by university restaurants in Brazil: A case study. J Clean Prod,. 161, 178-187. https://doi.org/10.1016/j.jclepro.2017.05.089

Tosatti, J. A. G., Bocardi, V. B, Jansen, A. K., et al. (2019). Determination of glycemic index of enteral formulas used in clinical practice. Int J Food Sci Nutr., 27, 1-10. https://doi.org/10.1080/09637486.2019.1634011

WBCSD (World Business Council for Sustainable Development). (2000). Eco-efficiency: Creating More Value with Less Impact. Geneva: WBCSD.

Wepoke (2018). Distância entre cidades. http://www.distanciasentrecidades.com/

Willett, W., Rockström, J., Loken, B., Springmann, M., et al. (2019). Food in the Anthropocene: The EAT-Lancet Commission on healthy diets from sustainable food systems. Lancet, 393, 447-492. https://doi.org/10.1016/S0140-6736(18)31788-4

Yu, W., \& Ramanathan, R. (2016). Environmental management practices and environmental performance: The roles of operations and marketing capabilities. Ind Manage Data Syst., 116 (6), 1201-1222. http://dx.doi.org/10.1108/IMDS-09-2015-0380 